\title{
INTERGOVERNMENTAL RELATIONS DALAM PEMBERIAN KONSESI HUTAN TANAMAN INDUSTRI DI PROVINSI RIAU
}

\author{
Zainal \\ Mahasiswa S3 Ilmu Pemerintahan FISIP UNPAD, Dosen Prodi Ilmu \\ Pemerintahan FISIP Universitas Islam Riau Pekan Baru. \\ Email: zainal.ip@soc.uir.ac.id
}

\begin{abstract}
Abstrak
Pemberian konsesi hutan tanaman industri di Provinsi Riau tidak hanya melibatkan aktor lokal namun juga melibatkan aktor internasional.Perusahaan swasta seperti PT. RAPP merupakan salah satu perusahaan yang memiliki konsesi hutan tanaman industri terluas di Provinsi Riau saat ini, perusahaan tersebut dan beberapa perusahaan lainnya sudah memiliki konsesi hutan tanaman industri sekitar 2,1 juta hekter di Provinsi Riau.Hasil penelitian ini menunjukan bahwa kebijakan sektor kehutanan kewenangan sepenuhnya menjadi milik Pemerintah Pusat,Pemerintah Daerah Provinsi hanya memiliki kewenangan pada tataran pemberian rekomendasi dan rekomendasi tersebut boleh dugunakan dan boleh juga tidak digunakan oleh Pemerintah Pusat sebagai pertimbangan dalam pemberian konsesi, untuk tingkatan Pemerintah Kabupaten/Kota setelah berlakunya Undang-Undang Nomor 23 Tahun 2014 tentang Pemerintahan Daerah kewenangan sektor kehutanan sudah dicabut dan bahkan dinas kehutanan sudah ditiadakan.Sehingga pada sektor kehutanan kebijakan pemerintah saat dapat disimpulkan kembali menjadi sentralistik. Secara teori intergovernmental relations yang digagas oleh Wrigh (1998) belum mampu menyentuh seluruh aktor yang terlibat dalam pemberian konsesi oleh karena itu diperkuat dengan teori intergovernmental relations yang digagas oleh Jones dan Royles (2012) yang menambahkan international actor sebagai salah satu dimensinya.
\end{abstract}

Kata Kunci: Intergovernmental Relations, Aktor, Konsesi Hutan 


\section{Zainal: INTERGOVERMENTAL RELATIONS.......}

\section{Pendahuluan}

Dalam kajian ini akan menjelaskan tentang intergovernmental relations dalam pemberian konsesi hutan tanaman industri bagi swasta di Provinsi Riau yang akan dijabarkan dalam data-data empiris dan dikaitkan dengan teori intergovernmental relations. Sektor kehutanan menjadi hal yang menarik untuk diteliti karena di satu sisi hutan merupakan hal yang terpenting bagi masyarakat yang hidup di kawasan hutan dan disisi lain merupakan peningkatan investasi. Sektor kehutanan di Indonesia saat ini dalam pemberian konsesi hutan tanaman industri bagi swasta sudah menjadi kewenangan pemerintah pusat dalam hal ini Kementerian Lingkungan Hidup dan Kehutanan Republik Indonesia dan menjadi dasar aturannya yakni UndangUndang Nomor 23 Tahun 2014 tentang Pemerintahan Derah. Keluarnya aturan tersebut juga mengakibatkan sudah tidak ada lagi kewenangan sektor kehutanan pada tingkat kabupaten/kota.

Provinsi Riau merupakan salah satu Provinsi di Indonesia yang mengalokasikan begitu besarnya luasan wilayahnya untuk konsesi hutan tanaman industri, pada tabel I.1 ini akan dijelaskan mengenai hal tersebut:

Tabel 1

Penggunaan Kawasan Hutan Provinsi Riau Untuk Pemberian Izin Kepada Perusahaan-Perusahaan yang bergerak di Bidang Hutan Tanmaan Industri

\begin{tabular}{|c|l|l|r|}
\hline No & \multicolumn{1}{|c|}{$\begin{array}{c}\text { Perizinan Kawasan } \\
\text { Hutan }\end{array}$} & $\begin{array}{c}\text { Jumlah } \\
\text { (Unit/Izin) }\end{array}$ & \multicolumn{1}{c|}{ Luas (Ha) } \\
\hline 1 & IUPHHK-HA & 5 & $5.499 .693,00$ \\
\hline 2 & IUPHHK-RE & 4 & $229.128,00$ \\
\hline 3 & IUPHHK-HT & 58 & $116.9777,00$ \\
\hline \multicolumn{2}{|l|}{ Luas Kawasan Hutan } & $1.660 .293,00$ \\
\hline
\end{tabular}

Jurnal TAPIs Vol. 14 No.02 Juli-Desember 2018 
Zainal: INTERGOVERMENTAL RELATIONS.......

\begin{tabular}{|c|c|c|c|}
\hline & $\begin{array}{ll}\text { a. Izin Menhut } \\
\text { b. Izin } \\
\text { Bupati/Walikota }\end{array}$ & $\begin{array}{l}49 \\
9\end{array}$ & $\begin{array}{r}1.600 .293,00 \\
59.325,00\end{array}$ \\
\hline 4 & IUPHHK-HHBK & 1 & $19.900,00$ \\
\hline 5 & $\begin{array}{l}\text { Pinjam Pakai Kawasan } \\
\text { Hutan } \\
\text { a. Tahap penetapan } \\
\text { b. Persetujuan Prinsip } \\
\text { c. KP }\end{array}$ & $\begin{array}{l}8 \\
10 \\
64\end{array}$ & $\begin{array}{r}376.729,97 \\
5.325,39 \\
14.275,82 \\
348.128,79\end{array}$ \\
\hline & Jumlah izin & 67 & $2,394.027,97$ \\
\hline & \multicolumn{2}{|c|}{ Sisa Kawasan Hutan } & $3.105 .665,03$ \\
\hline
\end{tabular}

Sumber: Dinas Lingkungan Hidup dan Kehutanaan Provinsi Riau Tahun 2015

Dari tabel di atas menunjukan bahwa hampir separoh dari luasan kawasan hutan di Provinsi Riau sudah diberikan kepada swasta melaui konsesi hutan tanaman industri yang sudah dikuasai oleh perusahaan. Ini membuktikan bahwa pemerintah selaku aktor yang memiliki kewenangan penuh dalam pemberian konsesi hutan tanaman industri sedang bersemangat meraih investasi yang sehat dalam sektor kehutanan di Indonesia. Jikalahari ${ }^{1}$ juga mengungkapkan bahwa proses deforestasi dan degradasi hutan alam di Provinsi Riau

\footnotetext{
${ }^{1}$ Jaringan Kerja Penyelamat Hutan Riau adalah sebuah organisasi yang berbentuk Forum dengan fokus kajian penelitian pada bidang kehutanan yang ada di Provinsi Riau dan merupakan sebuah organiasi yang fokus untuk memberikan kritis kepada pemerintah selaku pihak yang memberikan izin hutan kepada perusahaanperusahaan.
}

Jurnal TAPIs Vol. 14 No.02 Juli-Desember 2018 


\section{Zainal: INTERGOVERMENTAL RELATIONS.......}

berlangsung sangat cepat. Selama kurun waktu 24 tahun (1982-2005) Provinsi Riau sudah kehilangan tutupan hutan seluas 3,7 juta hekter. Pada tahun 1982 tutupan hutan alam di Provinsi Riau masih meliputi 78\% (6.415.655 hekter) dari luas daratan Provinsi Riau 8.225.199 hekter. Dalam kurun waktu tersebut rata-rata Provinsi Riau setiap tahunnya kehilangan hutan alam sekitar 160.000 hekter/tahun. ${ }^{2}$

Pada hal berbeda Cifor $^{3}$ juga menambahkan bahwa Indonesia adalah contoh yang baik karena berbagai alasan, pertama sebanyak 254 izin konsesi untukhutan tanaman industri (HTI) dikeluarkan pada tahun 2013 yang mencakup 10,1 juta hekter, hal ini mengambarkan peningkatan yang spektakuler dari hanya sembilan konsesi pada tahun 1995. Selama periode 2010 hingga 2014, area yang ditanami dalam konsesi ini meningkat dari 0,9 juta hekter menjadi 2,25 juta hekter, walaupun sumber dari kementerian Lingkungan Hidup dan Kehutanan menyatakan bahwa angka ini bisa mencapai 5 juta hekter. ${ }^{4}$ Dari hal tersebut membuktikan begitu luasnya hutan di Provinsi Riau saat ini sudah dikelola dan dikuasai oleh perusahaan swasta akan tetapi dari pemberian konsesi hutan tanaman industri seluas itu belum mampu memberikan kesejahteraan bagi masyarakat di Provinsi Riau

\footnotetext{
${ }^{2}$ Kajian Jikalahari Riau dengan Judul Fakta Kritis Analisa Tata Kelola Kehutanan di Provinsi Riau dalam website http://jikalahari.or.id/wpcontent/uploads/2016/03/FAKTA-KRITIS-ANALISIS.pdf diupdate pada tanggal 02-10-2018.

${ }^{3}$ Center for International Forestry Research (CIFOR) adalah lembaga nirlaba bersifat global yang berdedikasi untuk memajukan kesejahteraan umat manusia, pelestarian dan keadilan lingkungan. CIFOR melakukan penelitian yang memungkinkan pembuatan keputusan yang didasarkan pada informasi yang benar dan berkeadilan tentang penggunaan dan pengelolaan hutan di negara-negara berkembang.

https://id.wikipedia.org/wiki/Center_for_International_Forestry_Research

${ }^{4}$ CIFOR pada tahun 2016 menuliskan tentang Dampak Hutan Tanaman Industri di Indonesia Analisis Persepsi Masyarakat Desa Di Sumatera, Jawa dan Kalimantan pada latar belakang tulisannya menjelaskan bahwa Kementerian Lingkungan Hidup dan Kehutanan ada data hutan yang tidak terpublish secara keseluruhan kepada masyarakat ini sebenarnya membuktikan bahwasanya pemerintah selaku aktor yang memiliki kewenangan lebih besar daripada aktor lainya tidak bersifat transparan kepada masyarakat.
}

Jurnal TAPIs Vol. 14 No.02 Juli-Desember 2018 


\section{Zainal: INTERGOVERMENTAL RELATIONS.......}

khususnya masyarakat yang tinggal di sekitaran kawasan konsesi hutan tanaman industri.

Dari permasalahan yang ada di atas menunjukan begitu kompleksnya masalah dari sektor kehutanan terutama dari aspek konsesi hutan yang sudah diberikan pemerintah kepada pihak perusahaan. Selain aktor dari pemerintah (pemerintah pusat, pemerintah daerah, pemerintah kabupaten/kota), juga ada aktor dari swasta (perusahaan pemegang izin konsesi HTI), dan aktor masyarakat yang berada dalam ruang lingkup suatu negara akan tetapi ada juga aktor intenasional yang ikut juga berkontribusi dan mempengaruhi kebijakan sektor kehutanan di Indonesi oleh karena itu perspektif intergovernmental relations dianggap tepat dalam menganalisis masalah sektor kehutanan yang ada di Provinsi Riau. Karena dengan konsep IGR dapat melihat aktor-aktor yang saling berkepentingan satu dengan yang lainnya. Fatile dan Adejuwon (2009) menyebutkan bahwa intergovernmental relations merupakan hubungan secara vertical maupun secara horizontal antara pemerintah yang tinggi dengan memerintah yang lebih rendah dibawahnya dan saling melakukan koordinasi pada tiap tingkatan yang berupaya untuk mencapai tujuan dan kebijakan-kebijakan strategis yang akan dilakukan. ${ }^{5}$

Permasalahan sektor kehutanan yang terjadi di Indonesia sangat kompleks dan begitu banyak melibatkan aktor-aktor akan tetapi yang jauh lebih berperan adalah pemerintah selaku pemilik kewenangan tersebesar dan memiliki sumber daya yang lebih jika dibandingkan dengan domain private sector maupun dari domain civil society sector. Permasalahan demi permasalahan tersebut menunjukan bahwa pemberian izin yang tidak melihat kepada dampak yang ditimbulkan menjadikan tingkat deforestasi dan kerusakan lingkungan di Provinsi Riau semakin memburuk.

${ }^{5}$ Pengertian IGR menurut Fatile dan Adejuwon ini diilhami dari pandangan Olawu, Anderson, Watts and Adamokulen yang tertulis di dalam buku yang berjudul Local Government Administration in Nigeria Old and New Visions, Centre for Constitutionalism and Demilitarisation (CENCOD) Nigeria.

Jurnal TAPIs Vol. 14 No.02 Juli-Desember 2018 


\section{Zainal: INTERGOVERMENTAL RELATIONS.......}

Konsep intergovernmental relationsyang ditawarkan oleh Wright (1988) dianggap lebih tepat untuk melihat semua persoalan kehutanan yang ada di Indonesia khususnya di Provinsi Riau dan di dalam kajian ini juga dilengkapi dengan intergovernmental relations menurut Jones and Royles $(2012)^{6}$ yang juga menambahkan international actor sebagai salah satu aspek yang ikut berperan sebagai penentu perubahan kebijkan sektor kehutanan di dalam suatu negara.

\section{Pembahasan}

Pola hubungan antar tingkat pemerintah di Amerika dikenal dengan istilah intergovernmental relations (IGR) dan intergovernmental managemen (IGM) Mas'udi dkk dalam Warsono (2009) menambahkan bahwa pola pertama menjelaskan hubungan antar daerah merupakan koordinasi dalam rangka kerjasama untuk memperkuat posisi tawar ketika berhadapan dengan pemerintah yang lebih tinggi di atasnya. Pola yang kedua menggambarkan pola hubungan antara daerah terjadi dalam format kerjasama dalam pengelolaan urusan pemerintah tertentu yang merupakan kebutuhan mereka bersama. ${ }^{7}$

Anderson dan Gallagher (2018) memberikan pandangan bahwa intergovernmental relations merupakan dominasi rezim hubungan antar eksekutif dan dilakukan sebagian besar secara pragmatis yang berdasarkan kepada konstitusi. ${ }^{8}$ Eksistensi dari intergovernmental

\footnotetext{
${ }^{6}$ Royles, Elin dan Jones Richard (2012) Wales in the World: Intergovernmental Relations and Sub-State Diplomasi, The Britis Journal Politics and International Relations. Vol.14 Hal 250-269.

${ }^{7}$ Lebih lanjut di dalam ringkasan disertasi ini Warsono juga menambahkan bahwa dalam format networking, beberapa jenis intergovernmental network dalam derajat yang makin intensif dikemukakan oleh Robert Agranoff (2003) mulai dari information networks, development networks, outreach networks, sampai action networks.

${ }^{8}$ Dalam kajian Anderson dan Gallagher (2018) tentang Intergovernmental Relations in Canada and the United Kigdom menjelaskan tentang beberapa kesamaan antara penyelenggaraan pemerintahan di Canada dan Inggris dan mengemukakan bahwa Kanada berevolusi selama 150 tahun untuk menjadi sangat

Jurnal TAPIs Vol. 14 No.02 Juli-Desember 2018 


\section{Zainal: INTERGOVERMENTAL RELATIONS.......}

relations ada di dalam seluruh kegiatan pemerintahan yang diindikasikan dari dari phenomena global yang terjadi hal yang sama juga diungkapkan oleh Kahn (2011) dalam Pietersen (2017) $)^{9}$ yang mengkonformasi bahwa IGR merupakan sistem universal yang ada di dalam suatu negara yang secara konsen melakukan kegiatan yang cooperation dan coordination yang dilakukan oleh semua aktor yang terlibat baik secara vertical (hubungan pemerintah jenjang yang lebih tinggi dengan pemerintahan di bawahnya) maupun secara horizontal (hubungan pemerintah pada tingkatan yang sama) dan mempunyai hubungan yang erat dalam penyelenggaraan pemerintahan.

Secara lebih lengkap Wright (1988) menjelaskan bahwa intergovernmentalrelations terdiri atas lima fase yaitu adanyaall unit (multiple entities), adanya interanctions of officials (informal), adanya continuous andcumulative (regulates), adanya all public officials (administrator) serta adanya policy emphasis (fiscal focus). Pada tabel di bawah ini akan dijelaskan berbagai aspekyang ada pada kelima dimensi tersebut. ${ }^{10}$

Tabel 2.

Fitur khas dari Intergvernmental Relation (IGR)

\begin{tabular}{|l|l|l|l|}
\hline 1 & \multicolumn{2}{|l|}{ All Unit (Multiple entities) } & $\begin{array}{l}\text { 4. All Public } \\
\text { Officials } \\
\text { (Administrators) }\end{array}$ \\
\hline & National & Municipalities & Elected officials \\
\hline
\end{tabular}

terdevolusi tetapi pada dasarnya masih dengan sistem federasi yang simetris sementara Inggris dengan pola yang lama dtandai dengan hiper-sentralisme.

${ }^{9}$ Pietersen, Johny Masego, 2017. Intergovernental Relations: Delivery of Potable Water To Poor Comunities in Diepsloot of Gauteng Province. Merupakan doctor dalam bidang ilmu administrasi publik yang fokus melakukan kajian dari persfektif intergovernmental relations.

${ }^{10}$ Wright, (1988) Sage Publications, Inc is Collaborating with JSTOR to digitize, preserve and extend access to annals of the American Academy of Political Social Science

Jurnal TAPIs Vol. 14 No.02 Juli-Desember 2018 
Zainal: INTERGOVERMENTAL RELATIONS.......

\begin{tabular}{|c|c|c|c|}
\hline & $\begin{array}{l}\text { State } \\
\text { Counties }\end{array}$ & $\begin{array}{l}\text { Special district } \\
\text { School districts }\end{array}$ & $\begin{array}{ll}\text { a. } & \text { Legislators } \\
b . & \text { Executive } \\
c . & \text { Judges } \\
\text { Appointed } \\
\text { administration } \\
\text { a. } & \text { Generalists } \\
b . & \text { Functional } \\
& \text { specialists or } \\
& \text { program } \\
\text { professionals }\end{array}$ \\
\hline \multirow[t]{2}{*}{2} & \multicolumn{2}{|c|}{ Interactions of officials (informal) } & \\
\hline & $\begin{array}{l}\text { Behavior } \\
\text { Beliefs }\end{array}$ & $\begin{array}{l}\text { Perceptions } \\
\text { Preferences }\end{array}$ & \\
\hline 3 & \multicolumn{2}{|c|}{ Continuous and Cumulative (Regularities) } & $\begin{array}{l}5 . \\
\text { Emphasis (Fiscal } \\
\text { Focus) }\end{array}$ \\
\hline & \multicolumn{2}{|c|}{$\begin{array}{l}\text { Day-to-day contracts } \\
\text { Working relationships } \\
\text { Cumulative patterns }\end{array}$} & $\begin{array}{l}\text { Financial issues } \\
\text { Anchored in } \\
\text { politics } \\
\begin{array}{l}\text { Suffused with } \\
\text { policy }\end{array}\end{array}$ \\
\hline
\end{tabular}

Sumber: Wright, (1988) Sage Publications, Inc is collaborating with JSTOR

Fitur-fitur sebagaimana yang diungkapkan Wright (1988) dapat dijelaskan: bahwa pertama, hubungan antar pemerintah melibatkan semua unit-unit dalam pemerintahan dan menunjukkan

Jurnal TAPIs Vol. 14 No.02 Juli-Desember 2018 


\title{
Zainal: INTERGOVERMENTAL RELATIONS.......
}

keberagaman hubungan antara semua pemerintah. Kedua, hubungan menekankan interaksi diantara individu, khususnya pegawai negeri. Ketiga, hubungan berlangsung secara terus menerus dan bersifat normal. Keempat, hubungan tersebut menegaskan peran penting yang dimainkan oleh semua pejabat publik yang menjadikan mereka politisi atau administrator. Kelima, hubungan antar jenjang pemerintah menekankan hubungan yang bersifat politis dan bermuara pada kebijakan yang mendasar, terutama isu keuangan seperti siapa menghasilkan berapa banyak dan siapa membelanjakannya untuk keuntungan siapa dengan hasil apa.

Intergovernmental realtions Wright (1988) secara lebih rinci digambarkan oleh Agranoff dan Radin (2014) ${ }^{11}$ yang menambahkanhubungan pemerintah pusat, pemerintah daerah dan dengan pemerintah lokal ada hubungan yang bersifat authority, overlapping authority dan inclusive authority yang dapat dilihat pada gambar berikut.

Gambar 1

Models of national, state, and local reationships
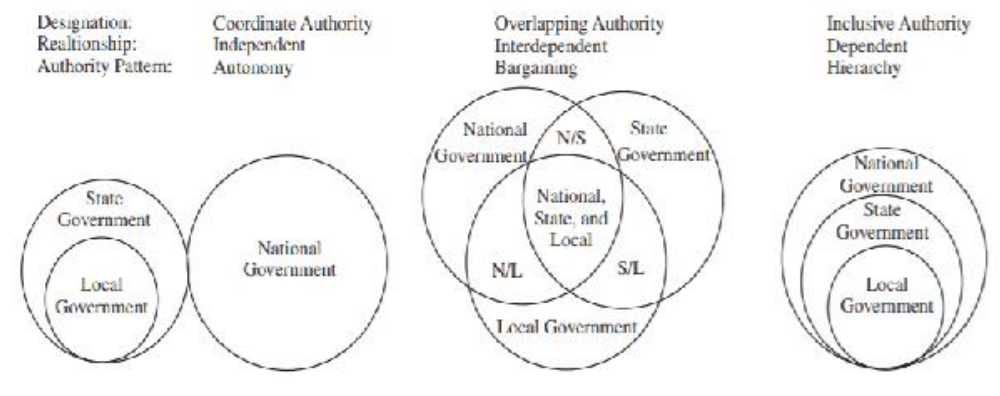

Sumber: Wright (1998)

\begin{abstract}
${ }^{11}$ Agranoff dan Radin, 2014. Deil Wright's Overlapping Model of Intergovernmental Relations' The Basis for Contemporary Intergovernmetal Relationsips; The Journal of Federalism, Published by Oxford University Press behalf of CSF Associates, Publius, Inc Hal. $1-21$.
\end{abstract}

Jurnal TAPIs Vol. 14 No.02 Juli-Desember 2018 


\section{Zainal: INTERGOVERMENTAL RELATIONS.......}

Agranoff dan Radin (2014) juga nenambahkan bahwa model yang digagas oleh Wright (1988) merupakan tiga model hubungan pada tingkat pemerintahan yang merupakan pengertian dari intergovernmental relations, yang sebenarnya sudah terlihat terhadap tiga hubungan antar tingkat pemerintahan, di dalam artikelnya juga menjelaskan bahwa ada overlapping modeldari kewenangan yang dimiliki oleh pemerintah pusat sehingga ini sangat mempengaruhi terhadap kebijakan pembangunan, hubungan program dan pelaksanaan kebijakan secara administrative dan semuanya itu sudah include menjelaskan tentang hubungan antara pemain pemerintah dan pemain diluar pemerintah itu sendiri yang sebenarnya bertujuan agar dimasa mendatang lebih membuka peluang pelaksanaanintergovernmental management di dalam penyelenggaraan pemerintahan.

Pandangan Wright (1988) begitu banyak mempengaruhi terhadap penyelengaraan pemerintahan negara-negara di dunia karena pandangannya tersebut begitu banyak dikaji dan diteliti oleh penelitipeneliti pada masa-masa sesudahnya dan ada juga peneliti yang beranggapan bahwa intergovernmental relations ini merupakan teori yang cocok walaupun dari awal teori ini dimunculkan sampai dengan sekarang sudah berusia sekitar 30 tahun. Karena penyelenggaraan pemerintahan negara-negara di dunia saat ini masih relevan jika dikaji dari persfektif intergovernmental relations.

Model intergovernmental relations (IGR) menurut Mays dan Taggaert (2005) secara konsisten menyebutkan bahwaIGR dibangun pada tiga rangkaian jenjang pemerintah yaitu pemerintah nasional, pemerintahdaerah, dan pemerintah lokal. ${ }^{12}$ Dari teori dan pandangan

\footnotetext{
${ }^{12}$ Lebih lanjut di Artikel Mays dan Tagart (2005) juga mengambil langkah dalam arah teoritis ini dengan memeriksa bagaimana permainan India mencerminkan banyak fitur khas yang mendefinisikan makna IGR. Secara khusus, artikel ini melihat pengalaman gaming India dari satu negara - New Mexico sebagai studi kasus untuk mengilustrasikan elemen hukum, manusia, dan kebijakan tentang apa yang mungkin dilihat sebagai mewakili munculnya patner antar pemerintah baru
} 


\section{Zainal: INTERGOVERMENTAL RELATIONS.......}

para ahli yang ada tersebut maka penulis menjadikan intergovernmental relations sebagai pintu masuk untuk menganalisis permasalahan konsesi hutan tanaman industri yakni melihat peranan pemerintah pusat, pemerintah daerah dan pemerintah kabupaten/kota.

Pembahasan dalam kajian ini hanya menggunakan satu dimensi yang digagas oleh Wright (1988) karena dari kelima dimensi yang ada penulis beranggapan lebih tepat menganalisis menggunakan dimensi all unitkarena dapat melihat peranan pemerintah pusat, peranan pemerintah daerah provinsi dan peranan pemerintah kabupaten/kota. Kemudian juga menambahkan international actor sebagai salah satu dimensi yang digagas oleh Royles dan Jones (2012).

\section{All Unit (Multiple Entities)}

Peranan Pemerintah Pusat

Pemerintah pusat dalam hal ini Kementerian Lingkungan Hidup dan Kehutanan Republik Indonesia merupakan lembaga yang berwenang penuh dalam pemberian izin hutan tanaman industri bagi swasta karena dengan berlakunya undang-undang nomor 23 tahun 2014 tentang Pemerintahan Deaerah semua kewenangan sektor kehutanan berpindah menjadi kewenangan pemerintah pusat. Di dalam UU Nomor 23 Tahun 2014 tentang Pemerintahan Daerah dikaitkan dengan UU Nomor 41 Tahun 1999 tentang Kehutanan dalam proses penerbitan konsesi Hutan Tanaman Industri menjadi tanggung jawab Kementerian Lingkungan Hidup dan Kehutanan (KLHK) namun dalam pelaksanaannya tidak bisa dilepaskan dari peranan pemerintah propinsi dan pemerintah kabupaten tempat dimana wilayah konsesi hutan tanaman industri berada.

Izin berawal dari persyaratan-persyaratan administrasi yang dilengkapi oleh perusahaan yang ingin mengurus izin hutan tanaman industri ke Kementerian Lingkungan Hidup dan Kehutanan (KLHK). Selanjutnya KLHK meminta rekomendasi kepada Gubernur Provinsi, selanjutnya Gubernur langsung melimpahkan ke Dinas Penanaman Modal dan Pelayanan Terpadu Satu Pintu Provinsi selanjutnya Dinas 


\section{Zainal: INTERGOVERMENTAL RELATIONS.......}

PMPTSP meminta pertimbangan teknis kepada Badan Koordinasi Penataan Ruang Daerah yang terdiri dari Ketua: Wakil Gubernur, Ketua Harian: Sekretaris Daerah dan Bapeda Provinsi kemudian Badan Koordinasi meminta Pertimbangan Teknis kepada Dinas Lingkungan Hidup yang berada di kawasan kabupaten. Setelah Dinas lingkungan hidup kabupaten mengatakan layak setelah dilakukan survey serta melihat kajian Amdal yang sudah lengkap itulah yang menjadi dasar gubernur mengeluarkan rekomendasi kepada KLHK setelah rekomendasi sampai ke KLHK barulah KLHK mengeluarkan konsesi Hutan Tanaman Industri, jika digambarkan dapat dilihat sebagai berikut:

Gambar 2

Proses Penerbitan Perizinan HTI Menurut UU No. 23 Tahun 2014

Tentang Pemerintahan Daerah dan UU No. 41 Tahun 1999 tentang Kehutanan

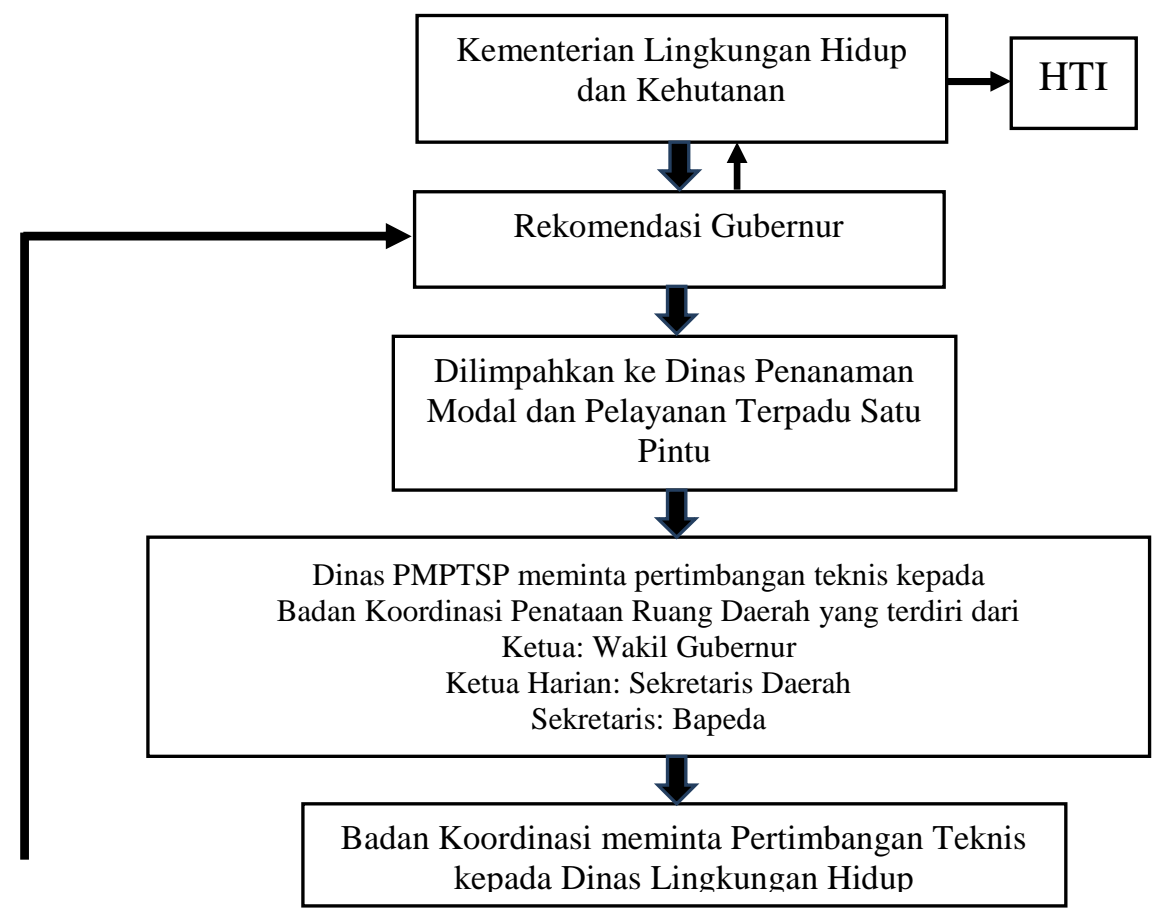

Jurnal TAPIs Vol. 14 No.02 Juli-Desember 2018 
Zainal: INTERGOVERMENTAL RELATIONS.......

Sumber:Modifikasi Peneliti Tahun Tahun 2018

\section{Peranan Pemerintah Daerah Provinsi}

Pemerintah Provinsi dalam hal ini Dinas Lingkungan Hidup dan Kehutanan Provinsi Riau merupakan salah satu lembaga yang ikut memberikan rekomendasi kepada pemerintah pusat dalam pemberian izin hutan tanaman industri di Provinsi Riau. Akan tetapi dengan kewenangan yang dimiliki oleh pemerintah provinsi sangat lemah karena hanya sampai pada batasan pemberian rekomendasi dan rekomendasi tersebut boleh dipakai dan boleh juga tidak dipakai oleh pemerintah pusat dalam pemberian konsesi hutan tanaman industri.

Berdasarkan hasil kajian yang dilakukan oleh Priyono dkk $(2016)^{13}$ menjelaskan bahwa keberhasilan pembangunan hutan tanaman industri diharapkan bagi pemerintah daerah lebih memperhatikan pendampingan terhadap pihak perusahaan dalam setiap melakukan pekerjaannya, guna sebagai fasilitator dan moderator sehingga masyarakat memiliki kepastian tentang penataan area kerja HTI, dan masyarakat bisa berpartisipasi secara aktif tanpa menimbulkan konflik. Pemberian sosialisasi oleh pihak pemerintah dan perusahaan kepada masyarakat harus lebih ditingkatkan, selanjutnya merealisasi setiap program yang disosialisasikan, agar masyarakat tidak menganggap sosialisasi tersebut hanya sebatas pertemuan semata. Setiap program dan kebijakan yang dilaksanakan kiranya mampu memberikan kontribusi kepada masyarakat sekitar untuk tetap berpartisipasi pada program yang dilaksanakan oleh perusahaan berdasarkan kebijakan yang diberikan.

Dari penelitian yang dilakukan tersebut mengungkapkan bahwa pemerintah daerah harus lebih meningkatkan peranannya

\footnotetext{
${ }^{13}$ Priyono dkk, 2016. Implementasi Kebijakan Hutan Tanaman Industri di Kabupaten Gorontalo Utara, Jurnal Sains \& Teknologi, Vol.16 No.2: 191 - 196. Hasil penelitian yang dilakukannya tersebut menunjukan bahwa implementasi kebijakan Hutan tanaman industri di Kabupaten Gorontalo Utara dari asoek penataan batas telah terelaisasi sepanjang $389,26 \mathrm{Km}$ atau $87 \%$ aspek penananaman terealisasi seluas 10,196.10 Ha, aspek penataan hasil hutan telah teretalisasi sesuai target dan aspek pengawasan dan pengendalian belum optimal sesuai perencanaan.
} 
dalam mengontrol areal yang akan dikelola oleh perusahaan dan ini dapat meminimalisir luasan lahan yang digarap oleh perusahaan, dengan demikian akan mengurangi konflik lahan yang terjadi antara perusahaan dan masyarakat. Dan jika sosialisasi yang dilakukan oleh pemerintah dan perusahaan secara continue dipastikan akan mampu meningkatkan partisipasi masyarakat yang berada di sekitaran konsesi hutan tanaman industri.

Kedepan diharapkan pemerintah daerah janganlah hanya memiliki kewenangan pada tataran pemberi rekomendasi akan tetapi rekomendasi tersebut mampu menjadi pertimbangan yang sangat penting bagi Kementerian Lingkungan Hidup dan Kehutanan dalam pemberian konsesi hutan tanaman industri bagi swasta. Karena konsesi tersebut tidak hanya menyangkut kepada pemerintah pusat sajaakan tetapi pemerintah daerah dan masyarakat yang berada dalam wilayah konsesi hutan tanaman industrilah yang menerima dampak secara langsung.

Terkait masalah yang terjadi di Provinsi Riau belum disahkannya Rencana Tata Ruang dan Wilayah (RTRW) juga mengakibatkan terhambatnya investasi sektor kehutanan dan pertambangan di Provinsi Riau karena jika RTRW belum disahkan maka Provinsi Riau tidak akan jelas mana yang menjadi wilayah pemukiman, wilayah perindustrian, wilayah perkebunan dan mana yang menjadi wilayah lahan gambut yang harus dilindungi karena memang izin yang diberikan dibeberapa wilayah di Provinsi Riau masuk ke dalam wilayah gambut yang meski dilindungi oleh negara.

Hasil penelitian Andiko (2017) ${ }^{14}$ juga menyebutkan bahwa supervisi dan kontrol untuk pemegang izin usaha adalah sangat

${ }^{14}$ Andiko, 2017. Studi Perbandingan Proses Pengakuan Hak dan Perizinan
Pengelolaan dan Pemanfaatan Hutan Serta Kawasan Hutan Untuk Masyarakat dan
Perusahaan; AsM Law Office. Batam. Pertanyaan pentingnya adalah, siapa
yang akan memberikan supervisedan kontrol kepada masyarakat yang
mengajukan izin dan mengelola hutan termasuk Hutan Adatyang
berdasarkan pengalaman, prosesnya sepenuhnya beradadi tangan
pusat. Kabupaten sebagaisatu kesatuan administratif terdekat tidak
105

Jurnal TAPIs Vol. 14 No.02 Juli-Desember 2018 
penting untuk pengendalianizin-izin. Supervisi dan kontrol akan memberikan dampak kepada keberhasilan pencapaianmaksud dari izin tersebut. Kewajiban monitoring dan supervisi pada perusahaan yang bergerak di bidang usaha HTI danrestorasi ekosistem hanya berada di Kementerian Lingkungan Hidup dan Kehutanan, sedangkanpada perusahaan di bidang usaha perkebunan kelapa sawit berada di Pemerintahan Kabupaten,Provinsi dan Kementerian Pertanian. Sama halnya dengan masyarakat untuk Hutan Kemasyarakatandan Hutan Desa kewajiban monitoring dan supervisi berada di Pemerintahan Kabupaten, Provinsi danKementerian Lingkungan Hidup dan Kehutanan. Namun demikian, terjadi sedikit kebingungan ketika diterbitkannya UU Otonomi Daerah yang baruyaitu UU No. 23 Tahun 2014 Tentang Pemerintahan Daerah yang menarik kewenangan Kehutanandari Kabupaten ke Provinsi.

Supervisi terhadap perusahaan penting dilakukan oleh pemerintah daerah tingkat provinsi karena jika kewenangan ini murni menjadi kewenangan pemerintah pusat maka akan sulit berjalan dengan maksimal mengingat pemerintah pusat berada di Jakarta sementara hutan-hutan yang dikelola oleh perusahaan berada di wilayah provinsi sehingga diharapkan dengan sinergi antara pemerintah pusat, pemerintah daerah provinsi dan pemerintah daerah kabupaten/kota diharapkan mampu meningkatkan controlpemerintah terhadap perusahaan, karena selama ini sudah terbukti begitu banyak perusahaan yang bergerak di bidang hutan tanaman industri yang kelebihan wilayah mereka kelola dengan luasan konsesi yang mereka dapati dari pemerintah.

Fakta lain juga terjadi bahwasanya di areal tanah yang sama terkadang dikuasai oleh beberapa perusahaan yang berbeda dan ini merupakan kelalaian dari control yang dilakukan pemerintah terhadap perusahaan pemegang izin dan hal ini bisa terjadi karena peta yang dipegang oleh pemerintah merupakan peta lama sehingga wilayah

memiliki lagi otoritas kehutanan. Jika otoritas ini diberikankepada Kesatuan Pengelolaan Hutan (KPH), skema yang tersedia hanyalah skema kemitraan dimanaareal yang dimitrakan adalah Hutan Negara.

Jurnal TAPIs Vol. 14 No.02 Juli-Desember 2018 


\section{Zainal: INTERGOVERMENTAL RELATIONS.......}

yang dulunya masih hutan sementara sekarang di lapangan wilayah tersebut merupakan wilayah pemukiman masyarakat yang berada di sekitaran konsesi hutan tanaman industri.

\section{Peranan Pemerintah Kabupaten/Kota}

Pada tingkat yang lebih rendah yakni pemerintah kabupaten/kota dengan berlakunya Undang-Undang nomor 23 tahun 2014 mengakibatkan kewenagan yang dimiliki mereka sudah tidak ada lagi dan sudah dicabut artinya tidak ada lagi dinas kehutanan pada tingkat kabupaten/kota. Dan ini membuat pemerintah kabupaten/kotasama sekali tidak dilibatkan dalam pemberian konsesi hutan tanaman industri sementara disatusisi yang lain wilayah yang akan digarap oleh perusahaan tersebut berada dalam lingkungan kekuasaan pemerintah tingkat kabupaten/kota. Ini membuat mereka semakin tidak memliki daya dan upaya apa-apa ketika jutaan hekter hutan di tempat mereka dikuasai oleh perusahaan-perusahaan penghasil kertas.

Berdasarkan kajian yang telah dilakukan oleh Syahadat dan Sylviani (2014) ${ }^{15}$ menjelaskan bahwa analisis kebijakan penyediaan lahan hutan tanaman industri adalah suatu kajian terhadap aturan main dalam penyediaan lahan untuk pembangunan hutan tanaman, dasar hukum serta upaya yang dilakukan oleh pemerintah untuk memberikan aspek legalitas lahan kepada pemegang izin IUPHHKHT untuk mengelola suatu kawasan hutan produksi. Aturan main yang dimaksud juga harus berpedoman kepada keseluruhan proses perizinan IUPHHK pada hutan tanaman, aturan main ini terdiri dari kriteria dan persyaratan yang harus dipenuhi, mekanisme penilaian yang digunakan termasuk pihak yang dapat melakukan penilaian dan cara penilaian yang memenuhi kriteria transparan,pastisipatif dan

\footnotetext{
${ }^{15}$ Syahadat dan Sylviani, 2014. Analisis Kebijakan Penyediaan Lahan Hutan Tanaman Industri, Jurnal Analisis Kebijakan Kehutanan, Vol 11 No.3, 227 296. Dalam kajian ini menunjukan bahwa tidak ada gap kebijakan dalam penyediaan lahan hutan tanaman, Pemerintah Daerah mengikuti mekenisme yang sudah ditentukan oleh Kementerian Lingkungan Hidup dan Kehutanan yang tertera dalam PP No.19 Tahun 2008 Jo PP No.11 Tahun 2008.
}

Jurnal TAPIs Vol. 14 No.02 Juli-Desember 2018 


\section{Zainal: INTERGOVERMENTAL RELATIONS.......}

akuntabel. Mekenisme permohoanan kepada Kementerian Lingkungan Hidup dan Kehutanan juga merupakan bagian dari aturan main karena dalam proses perizinan sangat terkait antara satu tahapan dengan tahapan lainnya.

Aturan main menjadi aspek penting yang harus diikuti oleh semua aktor karena dengan adanya pedoman maka pengambilan kebijakan sektor kehutanan terutama dalam pemberian konsesi hutan tanaman industri bagi swasta tidak mengakibatkan adanya pihak-pihak yang merasa dirugikan dengan kedatangan perusahaan dalam tatatanan kehidupan sosial masyarakat.

Terhadap pemberian konsesi hutan tanaman industri yang diperoleh di Pulau Padang Kabupaten Kepulauan Meranti menunjukan bahwa ada Amdal yang tidak ditaati oleh pemerintah dalam pemberian izin hutan tanaman industri dikarenakan begitu banyak ahli menyebutkan bahwanya di Pulau Padang berada dalam kawasan gambut yang semestinya dilindungi oleh pemerintah, dengan izin yang sudah dipegang oleh PT. RAPP masyarakat di daerah kawasan konsesi hutan tanaman industri tidak lagi dapat menolak kehadiran perusahaan karena pola pemberian konssi yang berlaku sekarang langsung pada tingkat pusat yaitu Kementerian Lingkungan Hidup dan Kehutanan Republik Indonesia. Tidak adanya Dinas Kehutanan pada tingkat Kabupaten/Kota di Indonesia menjadikan Pemerintah Kabupaten tidak bisa berbuat apa-apa karena pola pemberian izin hutan tanaman industri saat ini langsung pada tingkat pusat. Hal tersebut merupakan pola pelaksanaan penyelenggaraan pemerintahan dalam sektor kehutanan di Indonesia menjadi kembali kepada sistem yangsentralistik.

Kajian yang dilakukan Andiko (2017) ${ }^{16}$ izin usaha pemanfaatan hutan merupakan suatu dokumen yang wajib dimiliki dalam kegiatan pemanfaatan hutan. Proses perizinan pemanfaatan hutan oleh

${ }^{16}$ Di dalam kajian ini menjelaskan bahwa ada ketimpangan antara proses izin yang diurus oleh perusahaan dengan yang diurus oleh masyarakat ada begitu banyak di Indonesia saat ini beberapa kawasan hutan yang tidak produktif sehinga pemerintah harus berani menetapkan status hukum wilayah yang tidak produktif tersebut.

Jurnal TAPIs Vol. 14 No.02 Juli-Desember 2018 


\section{Zainal: INTERGOVERMENTAL RELATIONS.......}

perusahaan dan proses penetapan hak hutan adat untuk masyarakat adat menunjukan ketimpangan kemudahan dalam mengikuti proses, pemantauan proses perizinan yang berjalan dan berbagai kewajiban yang harus dilalui salah satu penyebabnya adalah pembuat peraturan perundang-undangan belum mempertimbangkan adanya ketimpangan kapasitas dan kemampuan yang besar antara perusahaan dengan masyarakat. Bisa dipastikan untuk memperoleh ruang perizinan dan penetapan hingga dapat memanfaatkan hutan, masyarakat tidak dapat mengikuti proses secara mandiri melainkan wajib mendapatkan pendampingan.

Artinya perlu bagi pemerintah pusat membagi kewenangan yang ada dan beberapa wilayah yang dianggap sudah tidak mampu lagi dikelola dengan baik maka pemerintah pusat harus memberikan kejelasan terhadap status hukum kawasan hutan tersebut seperti status hutan di kawasan taman nasional teso nilo di Kabupaten Pelalawan yang di tinggalkan oleh PT. RAPP wilayah tersebut merupakan hutan lindung yang sekarang tidak jelas mau dijadikan apa dan secara perlahan-lahan oleh aktor-aktor lokal wilayah tersebut ditanami sawit.

Kawasan yang ada di taman nasional teso nilo tidak lagi dikuasai oleh PT. RAPP karena izin mereka sudah dicabut oleh pemerintah karena pada kawasan tersebut merupakan izin konsesi yang dikuasai oleh perusahaan pada lokasi gambut yang harus dilindungi yakni dengan kedalaman di atas 3 meter, dulunya ketika Kementerian Lingkungan Hidup dan Kehutanan masih terpisah terjadi perbedaan analisis Amdal pada kawasan teso nilo setelah kedua kementerian itu bergabung maka analisis Amdal yang dipakai adalah analisis versi Kementerian Lingkungan Hidup.

\section{International Actor}

Intergovernmental relations Jones dan Royles (2012) mempunyai pandangan bahwa selain aktor dari central government dan local government tetapi kebijakan sektor kehutanan juga dipengaruhi adanya internationalactor dalam hal ini adalah para donator bank-bank di luar negeri yang menjadi pemodal bagi perusahaan RAPP dalam mengembangkan sayap perusahaannya dan 


\section{Zainal: INTERGOVERMENTAL RELATIONS.......}

memperluas hutan yang akan mereka tanami akasia sebagai bahan dasar untuk memproduksi kertas.

Demi menunjang aktivitas perusahaan dan memperluas ekspansi industri bubuk kertas, APRIL Grup mendapatkan banyak suntikan dana berupa kredit dari berbagai macam bank skala nasional maupun internasional. Bank Nasional yang memberikan kredit ke APRIL Group adalah Bank BNI dan Bank Mandiri, kedua bank tersebut memberikan kredit masing-masing US\$ 150 juta dan US\$ 471,26 juta pada tahun2005. Hingga akhir 2015, belum ada data terbaru yang menyebutkan bahwa bank Nasional tersebut kembali memberikan saluran kreditnya kepada APRIL Group. Hal ini bisa saja berkaitan dengan kebijakan green banking yang dianut oleh bank yang akanmenyalurkan kreditnya untuk perusahaan yang bergerak di bidang konsesi hutan tanaman industri. ${ }^{17}$

Pada tahun 2008 APRIL Group menjalin kerjasama kontrak dengan beberapa bank asal China, bank tersebut adalah Agricultural Bank of China, China Construction Bank, Industrial and Commercial Bank of China. Kesapakatan tersebut berupa kontrak penyaluran kredit sebesar RMB 7,8 miliar dalam jangka waktu 10 tahun, dan baru diberikan sebanyak RMB 1,8 miliar pada tahun 2008. Kredit tersebut akandigunakan April untuk membangun salah satu pabrik pengolahan pulp terbesar di dunia. April kembali mendapatkan bantuan kredit pada tahun 2011 dari bank ABN AMRO, bank tersebut merupakan bank yang dimiliki oleh pemerintah Belanda. Bank lain yang menyalurkan kreditnya pada tahun 2011 adalah China Development Bank, China CITIC Bank Internasional, Santander bank, dan WestLB. Dari ke 5 bank tersebut APRIL Grup menerima kredit sebesar US\$ 600 juta.

${ }^{17}$ Forest Watch Indonesia, 2015. Pelanggaran Perusahaan Hutan Tanaman Industri (HTI) dan Pembiayaan "Studi Kasus PT. Toba Pulp Lestarri dan April Group. Di dalam kajian ini menjelaskan bahwa begitu banyak pelanggaranpelanggaran yang dilakukan oleh perusahaan walaupun data dan fakta sudah dikaji oleh Forest Watch Indonesia namun oleh pemerintah tidak memberikan sanksi apapun kepada perusahaan-perusahaan tersebut.

Jurnal TAPIs Vol. 14 No.02 Juli-Desember 2018 


\section{Zainal: INTERGOVERMENTAL RELATIONS.......}

Tahun 2012 APRIL Group hanya mendapatkan saluran kredit dari Chang Hwa Bank sebesar US\$ 30 juta. Namun pada 2 tahun berikutnya, APRIL Group mendapatkan banyak suntikan dana kredit dari bank internasional lain. Pada tahun 2013, tercatat 13 bank yang berasal dari beberapa negara telah menyalurkan kreditnya ke APRIL Group dengan total investasi sebesar US\$ 980 juta. Sedangkan pada tahun 2014, terdapat 8 bank internasional yang memberikan kreditnya sebesar US\$ 215 juta kepada APRIL Group. Beberapa bank yang menyalurkan bantuan kredit kepada APRIL Group pada tahun 2014 telah melakukan hal yang sama pada tahun-tahun sebelumnya. Bank yang dimaksud adalah ABN AMRO (Belanda), China Development Bank, CITIC Industrial Bank, Santander, dan Taishin Internasional Bank.

Setelah mendapatkan banyak tekanan dan pengaduan dari beberapa pihak, akhirnyapada Maret 2015 bank Santander dan ABN AMRO menyatakan sikap tidak akan memperbaharui dan tidak memperpanjang kontrak pendanaan kepada APRILGroup sampai adanya ketaatan APRIL Group terhadap penerapan kebijakan baru yang ramah lingkungan. Untuk melihat lebih detail mengenai lembaga keuangan yang terlibat dalam pendanaan APRIL Group dapat dilihat pada gambar berikut ini.

Gambar 3

Pendanaan APRIL Group Dari Bank-Bank Di Luar Negeri dan Dalam Negeri

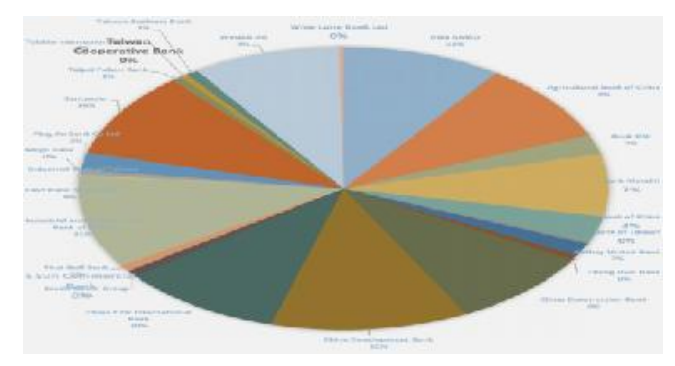

Jurnal TAPIs Vol. 14 No.02 Juli-Desember 2018 


\section{Zainal: INTERGOVERMENTAL RELATIONS.......}

Sumber: Forest Watch Indonesia Tahun 2015

Dari gambar dan penjabaran dalam tabel di atas bahwasanya pendanaan perusahaan-perusahaan yang bergerak di bidang hutan tanaman industri yang ada di Indonesia dan di Provinsi Riau terlihat dalam tabel di atas banyak berasal dari negara China yang menjadi mayoritas penyumbang terbesar dan itu menurut penulis bank-bank besar di China tersebutmerupakan bagian dari penyumbang kerusakan deforestasi dan degradasi hutan yang ada di Indonesia dan Provinsi Riau khususya. Adanya international actor yang terdiri dari perusahaan perbankan merupakan temuan dalam kajian ini perusahaan perbankan tersebut tidak terlalu memikirkan dampak negatif dan kerusakan terhadap lingkungan yang ada di Provinsi Riau dari peminjaman yang mereka berikan kepada swasta karena perusahaan hanya berorientasi kepada profit.

\section{Penutup}

Dari hasil penelitian ini diperoleh kesimpulan bahwa kebijakan sektor kehutanan yang ada di Provinsi Riau tidak hanya ditentukan oleh aktor-aktor dalam dalam negeri saja seperti pemerintah pusat, pemerintah daerah provinsi, pemerintah daerah kabupaten/kota, sektor swasta dan sektor masyarakat akan tetapi juga dipengaruhi oleh international actor seperti ikutnya bank-bank besar yang ada di berbagai negara dunia sebagai support dana kepada perusahaan yang bergerak dalam bidang hutan tanaman industri,secara langsung dapat dipahami bahwa kerusakan hutan di Indonesia saat ini juga dipengaruhi oleh international actor.

Dari pembahasan menggunakan teori intergovernmentalrelationsyang digagas Wright (1988) belum mampu melihat secara keseluruhan aktor-aktor yang terlibat dalam pemberian izin hutan tanaman industri dengan ditambahkannya dimensi international actormenurut Jones dan Royles (2012) diharapkan mampu memberikan kontribusi bagi pengembangan teori intergovernmental relations terutama berkaitan dengan konsesi hutan tanaman industri.

Jurnal TAPIs Vol. 14 No.02 Juli-Desember 2018 


\section{Zainal: INTERGOVERMENTAL RELATIONS.......}

\section{Daftar Pustaka}

Agranoff,Robert dan Radin, Beryl A, 2014. Deil Wright's Overlapping Model of Intergovernmental Relations' The Basis for Contemporary Intergovernmetal Relationsips; The Journal of Federalism, Published by Oxford University Press behalf of CSF Associates, Publius, Inc Hal. 1 - 21.

Anderson, George dan Gallagher Jim, 2018.Intergovernmental Relations in Canada and the United Kigdom. Constitutional Politics and The Territorial Question Canada and The United Kigdom. http://www.springer.com/978-3-319-58073-9

Andiko, 2017. Studi Perbandingan Proses Pengakuan Hak dan Perizinan Pengelolaan dan Pemanfaatan Hutan Serta Kawasan Hutan Untuk Masyarakat dan Perusahaan; AsM Law Office. Batam.

Data Statistik Dinas Kehutanan Provinsi Riau Tahun 2014

Fatile dan Adejuwon, Local Government Administration in Nigeria Old and New Visions, Centre for Constitutionalism and Demilitarisation (CENCOD) Nigeria.

Forest Watch Indonesia, 2015. Pelanggaran Perusahaan Hutan Tanaman Industri (HTI) dan Pembiayaan "Studi Kasus PT. Toba Pulp Lestari dan April Group.

http://jikalahari.or.id/wp-content/uploads/2016/03/FAKTA-KRITISANALISIS.pdf diupdate pada tanggal 02-10-2018.

https://id.wikipedia.org/wiki/Center_for_International_Forestry_Resea rch diupdate pada tanggal 02-10-2018

Mays dan Tagart, 2005.Intergovernmental Relatons and Native American Gaming A Case Study on the Emergence of a New Intergovernmental Relations Participant. American Review of Public Administration; Vol.35 No.1 74-93.

Pietersen, Johny Masego, 2017. Intergovernental Relations: Delivery of Potable Water To Poor Comunities in Diepsloot of Gauteng Province. 


\section{Zainal: INTERGOVERMENTAL RELATIONS.......}

Priyono dkk, 2016. Implementasi Kebijakan Hutan Tanaman Industri di Kabupaten Gorontalo Utara, Jurnal Sains \& Teknologi, Vol.16 No.2: 191 - 196.

Royles, Elin dan Jones Richard, 2012.Wales in the World: Intergovernmental Relations and Sub-State Diplomasi, The Britis Journal Politics and International Relations. Vol.14 Hal 250-269.

Syahadat dan Sylviani, 2014. Analisis Kebijakan Penyediaan Lahan Hutan Tanaman Industri, Jurnal Analisis Kebijakan Kehutanan, Vol 11 No.3, 227 - 296.

Warsono Hardi, 2009. Regionalisasi dan Manajemen Kerjasama Antar Daerah (Studi Kasus Dinamika KerjasamaAntarDaerah Yang Berdekatan di Jawa Tengah), Program Doktor Ilmu Administrasi UGM; Yogyakarta.

Wright, Deil. 1988. Sage Publications, Inc is Collaborating with JSTOR to digitize, preserve and extend access to annals of the American Academy of Political Social Science

Jurnal TAPIs Vol. 14 No.02 Juli-Desember 2018 